\title{
Legal Termination of Employment: Investigating the relationship between Performance Appraisal and Legal Termination
}

\author{
Sinan Bahaulddin Mohammed
}

\author{
Master in Public Law, Erbil, Kurdistan Region of Iraq \\ Received: 11 May 2021; Received in revised form: 11 Jun 2021; Accepted: 21 Jun 2021 \\ (C2021 The Author(s). Published by TheShillonga. This is an open access article under the CC BY license \\ (https://creativecommons.org/licenses/by/4.0/)
}

\begin{abstract}
The primary goal of this study is to look at the link between annual performance appraisals at private hospitals and legal termination; specifically, the study looked at whether employees are fired for poor performance after being appraised by performance appraisal management. This study employed a quantitative way to analyze data from four different private hospitals to determine whether employees are fired for poor performance after being reviewed by a performance assessment management system. A total of 100 questionnaires were issued, however only 68 were returned. The findings of this study revealed that in private hospitals, there is a poor and weak link between performance appraisal evaluation and legal termination.
\end{abstract}

Keywords-Erbil, Legal Termination, Performance Appraisal, Private Hospitals.

\section{INTRODUCTION}

Legally terminating employees is almost definitely the most important move a firm can make in today's environment (Ali \& Anwar, 2021). The major goal of this study is to look at the link between annual performance appraisals at private hospitals and legal termination; specifically, the study looked at whether employees are fired for poor performance after being appraised by performance appraisal management (Saleh et al. 2021). Individual and group contributors' abilities and skills are developed through performance management, which is described as a strategic approach for increasing organizational effectiveness by enhancing employee performance and growing individual and group contributors' talents and skills (Ali et al. 2021).

Unfair termination of employment refers to the procedure of dismissing an employee without providing a legitimate reason for the dismissal. It is the dismissal of an employee from their job for reasons that are not legally justified. Unfair dismissal claims are generally not admissible in situations where an employee is fired due to actual redundancy, incapability, or misconduct, according to the law (Abdullah et al. 2017). The process of removing someone from their job is included under the category of disciplinary action inside the office structure (Sabir et al.
2021). Administrative actions done by management against an employee who fails to comply with rules and regulations set inside the organization are known as disciplinary actions. Anwar, (2017) went on to say that employers have legal jurisdiction in the issuing of orders and the implementation of restrictions or sanctions in order to guarantee that the rules are followed and that employees comply with them. Normally, employers expect their employees to adhere to general society and managerial work regulations, and to refrain from engaging in improper behaviors such as fighting, stealing, intoxication, sexual and racial discrimination, insubordination, and poor performance, among other things (Anwar \& Balcioglu, 2016). There are several instances of unfair grounds for implementing these disciplinary procedures in offices where employers have obtained legal custody of their employees. This document tries to correct the injustice and unfair termination of employment that has occurred as a result of the actions of the employer. The majority of employees are still engaged in the battle for their own rights in relation to management (Hameed \& Anwar, 2018). Their prospects are still in the hands of labor unions. In their opinion, it is only through trade unions that they can obtain greater bargaining power in order to bargain for an increase 
in their low salary, to minimize discrimination in promotions and transfers as well as pay, or by being unfairly dismissed, to win participation in discussions about issues affecting their interests, and to maintain peace of mind by acquiring freedom of self expression and a better relationship with management. On the contrary, all of one's efforts and expectations are ultimately in naught. Despite the fact that employees' rights continue to be violated, they have gained only a limited collective bargaining power, their right to freedom of expression has been taken away, and they are left with their grievances and complaints. The case of an employee who was fired for violating the company's non-smoking policy was particularly interesting because, while the company had a non-smoking policy in place, the consequences of violating the policy were not known or enforced, and the policy itself was also not adhered to in the case at hand (Anwar \& Ghafoor, 2017). This serves as a reminder to employers that the implementation of any workplace policies must be compatible with efforts to ensure that they are followed. The case of 700 mineworkers in Tanzania, who were unfairly dismissed, can serve as a practical example of unfair dismissal (Anwar \& Climis, 2017). In July 2010, a Tanzanian court affirmed their unfair dismissal suit. These individuals had previously worked at the Bulyanhulu underground gold mine in Shinyanga, Tanzania, and were ex-miners. Following a collapse in salary negotiations in 2007, the miners were fired for their participation in a strike that year. The mine temporarily halted production for several weeks before terminating all 1,300 striking workers, accusing them of engaging in illegal strike activity. While some of the employees were later rehired, the majority of them were represented in court. In a complaint filed with the International Labor Organization, the Tanzania Mines, Energy, Construction and Allied Workers' Union accused the company that employs them, Barrick gold mine, Tanzania Ltd, of improper labor practices (Anwar, 2017). The Sun flag textile plant in Tanzania was another instance of unjust layoff of employees in Tanzania. The company employs 2,100 people who work in shifts throughout the day and night to ensure that it is open 24 hours a day. Clothing, such as T-shirts and dresses, are manufactured by Sun Flag, which also makes lengths of material for retail outlets and individual labels in industrialized countries. In February 2008, around 350 workers who were protesting the low salaries offered by their employer, which were lower than the wages authorized by the government, were unfairly removed from their jobs. Later, around one hundred employees were rehired at another corporate manufacturing facility (Anwar \& Qadir, 2017).

\section{LITERATURE REVIEW}

Work performance was abstracted by Anwar \& Abdullah, 2021) to include both contextual and job performance. Furthermore, they demonstrated that job performance refers to the skill with which an individual performs, whereas contextual performance refers to additional duty capabilities that are primarily related to the organizational environment, psychological, and social, in order to aid in the achievement of organizational objectives or goals (Anwar \& Louis, 2017). Contextual factors include characteristics such as putting in extra effort and excitement, volunteering to help with work, and authorizing and supporting an organizational aim or set of goals (Anwar, 2017). According to Anwar \& Qadir, 2017), performance appraisal is a procedure that specifies how an individual performs a task and connects those information back to the individual. Furthermore, it is indicated that performance appraisal gives data for human resource management actions such as terminating, promoting, merit pay, and legal termination (Anwar, 2017). The data from the performance appraisal could also be used to track employee effort and contribution for future training and development (Anwar \& Climis, 2017). Furthermore, performance appraisal provides opportunities for participation and involvement in the approval of selecting actions and human resource planning (Anwar \& Ghafoor, 2017). Managers and other external sources, such as stakeholders such as customers, evaluate an individual's performance. Performance evaluation can be done in a variety of ways (Hameed \& Anwar, 2018). There are three primary kinds of approaches to consider. Graphic Rating Scales (GRS) are the first category of performance appraisal methodologies; they are the most often used method and technique for performance rating. Employees will be measured or evaluated using a five-point scale or a seven-point scale in this methodology (Anwar \& Balcioglu, 2016). Comparison tactics, which include forced distribution, rank-order, and paired comparisons among employees, make up the second group of performance appraisal approaches. Employees will be evaluated against one another using this method. Individuals will be assessed on a supplied performance measurement from high to poor, using the rank-order methodology. However, because the rank-order methodology has ordinal scale properties, performance assessment and evaluation will be less precise. Furthermore, using the paired comparison methodology, each individual within an organization will be compared to other individuals and both will be evaluated in order to determine who is the greatest. The method is typically used to assess an individual's overall ability to accomplish a task. Finally, when the number of individuals being examined is large (Ahmed et al. 2021), the forced distribution strategy is considered an effective strategy among all methods. 
Individuals and measures ranging from poor to good are assigned to individuals using this methodology (Sabir et al. 2021). The third group is behavioral checklists (Hamza et al. 202). This group is consisted of the practices such us (BOS) behavioral-observation scales, (MSRS) mixed standard rating scales and (BARS) behaviorally anchored rating scales (Anwar \& Abd Zebari, 2015). The first group which is BOS is created to enhance BARS. In this case, the evaluators assess an individual on the rate of recurrence of serious incidents or particular individual behaviors (Sorguli et al. 2021). The evaluator observes the subject for a set amount of time and rates him or her on a scale of seriousness (Abdullah et al. 2017). The second group (MSRS) is concerned about the nature of the performance aspect as well as the defined levels of performance (Anwar \& Surarchith, 2015). In this situation, an individual is graded based on the reactions of the assessors to the performance dimensions. Evaluators respond to a certain behavior that demonstrates the average, (Anwar \& Shukur, 2015) low, and high performance dimensions for each performance dimension. Finally, BARS stands for a combination (Aziz et al. 2021) or integration of rating scale methodologies and behavioral incidents. Individuals' performance will be evaluated on a unanchored scale in this situation (Anwar, 2016)

The employers' right to discipline their employees is presented on the failure of the workers to fulfill their duties and responsibilities under the contract of employment which involves giving honest and faithful service by using relevant skills, care and all reasonable orders and not otherwise (Anwar, 2017). Employers are not always right; sometimes they can act unreasonably just because of over ambitions toward their workers performance, and behaviors. It is during this time they can act and take awkward decisions of dismissing employees without considering the formal procedures and the provision of laws on the fair termination grounds. In discussing employees right basing on fair grounds of termination of employment (Anwar \& Louis, 2017) provides that during the hearing of the case the commission must determine whether on the balance of probabilities, the dismissal is harsh, unjust, or unreasonable, and they must have regard to the termination of employment convention, rules and procedures for termination. In the United States, situation is inconsistent just because the majorities of private sector employees almost 50 million are unorganized and have no protection against unfair dismissal. Their hope is when they can think of fit in themselves into the specific statutes designed to protect employees against discrimination of race, age, sex, disability and nationality (Anwar \& Abdullah, 2021). For the case of employees who work under collective bargaining agreement, 25 percent of the total workforce acquires strong protection against unfair discipline of any kind including termination of employment (Ali et al. 2021). According to Saleh et al. (2021) revealed the grounds for unfair dismissal if there is an application of invalid reason. The invalid reason is when an employee is alleged for a temporary absence from work because of illness, or injury or his spouse has given birth to a child. Ali \& Anwar, (2021) also mentioned unjustifiable reasons for termination like being a member of any trade union, physical and mental disability, marital status, sex, age preferences, and gender. If termination of employment was done under those circumstances then the employees have legal right to apply for reinstatement (Anwar \& Shukur, 2015). The act provides that the application for reinstatement must be made within the 21 days after the dismissal to be dealt. Ahmed et al. (2021) added that employers are prohibited from discriminating in anyway against employees who reported unfair employers labor practices hence employees should feel free to use their right of being reinstated when they are treated unfairly. The General Protection Provision of the fair work Act (2009) listed some of the fair grounds that justifies termination of employment as when the employee refuses to obey the employer's lawful instructions, repeatedly inefficiency, incompetence at workplace, or where the employer has given clear warning that the employee's work is unsatisfactory and yet no improvement has been made regardless of given ample time to rectify the situation, and misconducts like drunkenness, drugs, assault, serious breaches of work safety standards, dishonesty, or criminal acts. The act concluded that not all misconduct will justify termination of employment but it depends on many factors like how serious the misconduct was (Hamza et al. 2021). In order to protect employee's rights from biasness of employer's decisions, according to Anwar \& Abd Zebari, (2015), it is unlawful to terminate the employment of anemployee unfairly. The unfair grounds according to the act include the failure of employer to prove the validity of the reason for termination and termination should be done in accordance with fair procedure. According to Sorguli et al. (2021), provides that it shall not be a fair reason to terminate employment of an employee for reasons related to pregnancy, disability, being a member of any trade union and if employees fail or refuses to do anything that an employer may not lawfully permit or require the employee to do (Anwar \& Surarchith, 2015). The Act insists on the importance of providing proof during the proceedings concerning unfair termination of an employee by an employer (Anwar \& Shukur, 2015).

The failure of employees to fulfill their duties and responsibilities under the contract of employment, which includes providing honest and faithful service by employing necessary abilities, care, and following all reasonable 
directions, is offered as justification for employers to penalize their employees (Anwar, 2017). Employers are not always correct; sometimes they can act in an unreasonable manner simply because they have unrealistic expectations of their employees' performance and behavior. It is during this period that they might act and make unpleasant decisions about dismissing employees without taking into consideration the formal procedures and the provisions of applicable legislation about reasonable grounds for termination (Aziz et al. 2021). Regarding employee rights based on fair grounds for termination of employment, the Industrial Relations Commission of South Australia, pursuant (Anwar, 2016), provides that during the hearing of the case, the commission must determine whether the dismissal is harsh, unjust, or unreasonable, and they must take into consideration the reasons for the termination of employment, as well as the circumstances surrounding the termination of employment. In the United States, the situation is contradictory simply because the vast majority of private sector employees (about 50 million) are unorganized and do not have any protection against wrongful dismissal from their employers (Ali et al. 2021). Their aim is that they will be able to fit themselves into the special statutes established to protect employees against discrimination on the basis of color, age, gender, handicap, and nationality when they are able to think of something (Abdullah et al. 2017). Employees who are covered by a collective bargaining agreement account for 25 percent of the overall workforce, and they are afforded substantial protection against unjust discipline of any type, including dismissal (Sabir et al. 2021). according Anwar \& Balcioglu, (2016), established the grounds for unfair dismissal in the event that an invalid reason is used in the application process. When an employee is said to be absent from work for a temporary period of time due to illness or accident, or when his or her spouse has given birth to a child, the claim is invalid. Under the General Protection Provision (Anwar, 2017), it is also prohibited from terminating an employee for unjustified grounds such as being a member of any trade union, having a physical or mental handicap, marital status, gender, sexual orientation, or age preferences (Hameed \& Anwar, 2018). If an employer terminates an employee's employment under specified circumstances, the employees have the legal right to file a claim for reinstatement (Anwar $\&$ Ghafoor, 2017). The act stipulates that an application for reinstatement must be filed within 21 days of the dismissal in order for it to be considered for consideration. Anwar \& Climis, (2017) went on to say that employers are banned from discriminating in any way against employees who report unlawful employer labor practices, and as a result, employees should feel free to use their right to be restored if they believe they have been unfairly handled (Anwar, 2017). Some of the fair grounds that justify termination of employment, including when an employee refuses to obey the employer's lawful instructions, when an employee is inefficient or incompetent at work on a regular basis (Anwar \& Qadir, 2017), or when the employer has given clear warning that the employee's work is unsatisfactory and yet no improvement has been made regardless of $\mathrm{g}$. The act came to the conclusion that not all misconduct will justify termination of employment, but that it is dependent on a variety of variables, including the severity of the misconduct (Anwar, 2017).

To safeguard employees' rights from being violated by their employer's actions that are influenced by their gender, according to the statute (Anwar \& Louis, 2017), unfair reasons for termination include the inability of the employer to demonstrate the legitimacy of the reason for termination and the failure to terminate in accordance with a fair procedure (Anwar \& Abdullah, 2021). It is not a fair reason to terminate the employment of an employee for reasons related to pregnancy (Ali et al. 2021), disability, membership in a trade union, or if the employee fails or refuses to do anything that the employer may not lawfully permit or require the employee to do under the circumstances (Saleh et al. 2021). The Act emphasizes the need of providing evidence during the course of a legal procedure involving the unjust termination of an employee by an employer (Ali \& Anwar, 2021).

Research Hypothesis: Higher employee performance level led to decrease number of employees 'legal termination.

\section{METHODOLOGY}

The study was carried out at four different private hospitals in Erbil. The main purpose of this research is to analyze the association between the annual performance appraisal evaluation and legal termination at private hospitals. A quantitative method was used in this research to analyze the gathered data from four different private universities to find out whether employees are terminated based on their poor performance after being evaluated by performance appraisal management system. 100 questionnaires have been distributed, however only 68 questionnaires were received. 


\section{DATA ANALYSIS}

Table 1-Demographic Analysis

\begin{tabular}{|c|c|c|c|}
\hline Items & & Frequency & Percent \\
\hline \multirow[t]{2}{*}{ Gender } & Male & 38 & 55.1 \\
\hline & Female & 31 & 44.9 \\
\hline \multirow{7}{*}{ Age } & $18-22$ & 11 & 15.9 \\
\hline & $23-26$ & 21 & 30.4 \\
\hline & $27-32$ & 17 & 24.6 \\
\hline & $33-38$ & 8 & 11.6 \\
\hline & $39-44$ & 7 & 10.1 \\
\hline & $45-49$ & 3 & 4.3 \\
\hline & $50+$ & 2 & 2.9 \\
\hline
\end{tabular}

Table (1) shows the demographic analysis for the current study. As for participants' gender; 38 participants were male and 31 participants were female. As for participants ${ }^{\circ}$ age; 11 participants fall in a group of 18-22 years old, 21 participants fall into a group of 23-26 years old, 17 participants fall into a group of 27-32 years old, 8 participants fall into a group of 33-38 years old, seven participants fall into a group of 39-44 years old, three participants fall into a group of 45-59 years old and only two participants fall into a group of 50 years old and above.

Table 2-Reliability Analysis

\begin{tabular}{|c|r|r|}
\hline Factors & Cronbach's Alpha & N of Items \\
\hline Performance appraisal & & .874 \\
\hline Legal termination & .864 & 14 \\
\hline
\end{tabular}

Table (2) shows the reliability test for performance appraisal as independent factor and legal termination as dependent factor. The Cronbach Alpha for performance appraisal $=.874$ for 14 items which is more than .6 accordingly performance appraisal's fourteen items used in this study were reliable and The Cronbach Alpha for legal termination $=.864$ for 12 items which is more than 6 accordingly legal termination's twelve's items were reliable. 
Table 3-Correlation Analysis

\begin{tabular}{|l|l|r|r|}
\hline Factors & Pearson Correlation & Performance Appraisal & Legal Termination \\
\hline & & & \\
\hline Performance & Pearson Correlation & 1 & $.781^{\text {** }}$ \\
\hline Appraisal & Sig. (2-tailed) & & .000 \\
\hline & $\mathrm{N}$ & 68 & 68 \\
\hline Termination & Pearson Correlation & $.781^{\text {** }}$ & 1 \\
\hline & Sig. (2-tailed) & .000 & 68 \\
\hline & $\mathrm{N}$ & 68 & \\
\hline
\end{tabular}

**. Correlation is significant at the 0.01 level (2-tailed).

Table (3) shows the correlation analysis between performance appraisal as independent variable and legal termination as dependent variable. The Pearson correlation value $=.781^{* *}$ which is greater than 0.01 this indicates that there is a positive and strong correlation between performance appraisal and legal termination in private hospitals in Erbil, Kurdistan.

Table 4- Model Summary

\begin{tabular}{|l|r|r|r|r|}
\hline Model & R & R Square & Adjusted R Square & Std. Error of the Estimate \\
\hline 1 & $.781^{\mathrm{a}}$ & .610 & .604 & .45479 \\
\hline
\end{tabular}

a. Predictors: (Constant), Performance Appraisal

In table (4) the value of $\mathrm{R}$ Square is .610 which means that $61 \%$ of the variables are explained.

Table 5- ANOVA

\begin{tabular}{|c|c|c|c|c|c|c|}
\hline Model & & Sum of Squares & $\mathrm{df}$ & Mean Square & $\mathrm{F}$ & Sig. \\
\hline 1 & Regression & 21.383 & 1 & 21.383 & 103.383 & $.000^{\mathrm{b}}$ \\
\hline & Residual & 13.651 & 66 & .207 & & \\
\hline & Total & 35.035 & 67 & & & \\
\hline & & & & & & \\
\hline
\end{tabular}

a. Dependent Variable: Legal termination

b. Predictors: (Constant), Performance Appraisal

Table (5) shows the value of $\mathrm{F}$ for both factors is $103.383>1$ which indicates there is a significant association between performance appraisal and legal termination. 
Table 6-Coefficients

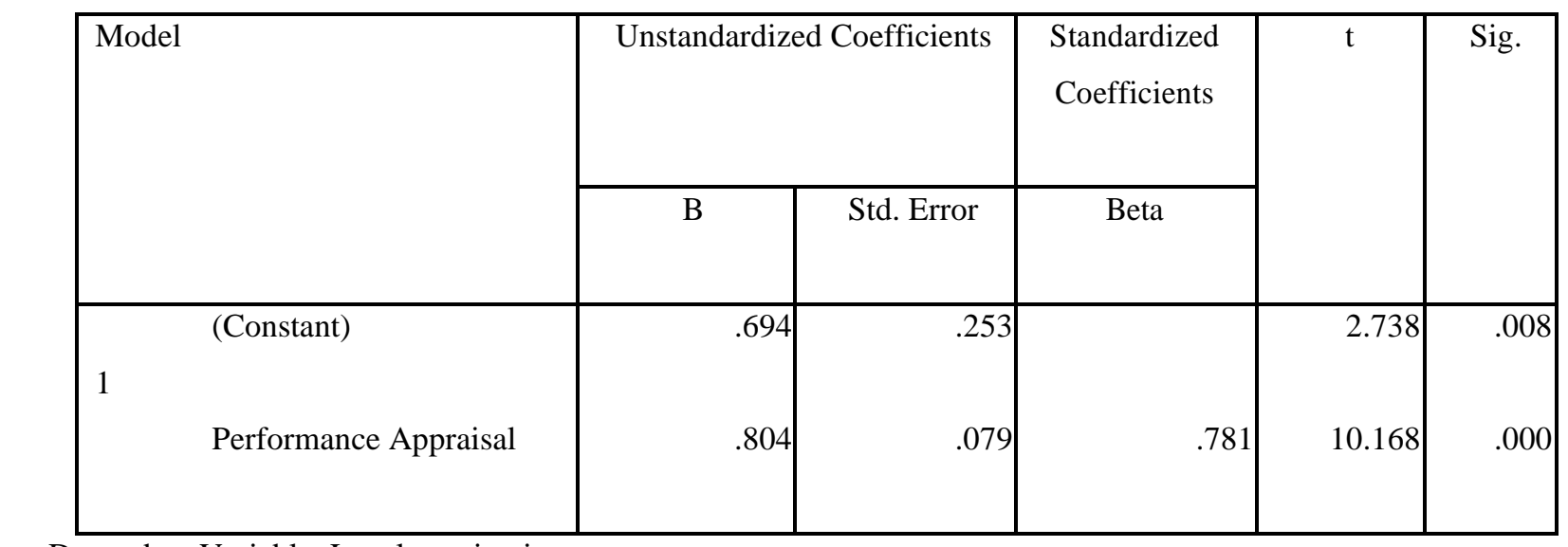

a. Dependent Variable: Legal termination

The value Beta $=.781$ as seen in table (6) is greater than 0.01 which means that there is a positive and strong relationship between performance appraisal and legal termination in private hospitals in Erbil, Kurdistan.

\section{CONCLUSION}

Every hospital should document the explanations and assessment for the termination decision. Integrity is improved with documented performance appraisal assessments and cases of poor performance. Hospitals should be able to provide certain procedure of performance evaluator or an effective guidance to help poor performers in enhancing their performance. The result of this research demonstrated that there is poor and weak association between the evaluation of performance appraisal and legal termination at private hospitals.

Also demonstrated was the fact that, while job performance refers to the skill with which an individual performs, contextual performance refers to additional duty capabilities that are primarily related to the organization's environment, including the psychological and social aspects of it, in order to aid in the achievement of organizational objectives or goals. In addition to characteristics such as putting forth extra effort and excitement, volunteering to assist with work, and authorizing and supporting an organizational goal or set of goals, contextual factors include characteristics such as putting forth extra effort and excitement, volunteering to assist with work, and authorizing and supporting an organizational goal or set of goals. The technique of performance appraisal, according to Yusoff (2014), explains how a person completes a task while also connecting the collected information back to the individual. According to the authors, performance appraisal provides information that can be used for human resource management actions such as firing, promotion, merit pay, and legal termination, among others. Furthermore, the information gathered from the performance appraisal could be utilized to track employee effort and contribution in order to plan for future training and development opportunities. Furthermore, performance appraisal provides opportunities for participation and involvement in the approval of selected actions as well as human resource planning, among other activities. Evaluation of an individual's performance is conducted by managers and other external sources, such as stakeholders such as customers. Performance evaluation can be carried out in a number of different ways. There are three main types of techniques to take into consideration. Individuals will be evaluated on a performance measurement that has been provided, ranging from excellent to poor, according to the rank-order methodology. However, due to the ordinal scale qualities of the rank-order methodology, performance assessment and evaluation will be less exact than in other methodologies. The paired comparison methodology will also be used to compare and analyze the performance of each employee within a company in order to decide who is the most outstanding of them all. In most cases, the approach is employed to determine an individual's overall capacity to complete a given activity. Finally, when there are a big number of persons being investigated, the forced distribution strategy is believed to be the most effective strategy among all of the available options. By employing this system, individuals are assigned to different individuals and different measures ranging from poor to good. Specifically, the incidence of recurrence of significant incidents or specific individual behaviors is taken into consideration by the assessors when assessing a person. The subject is observed by the evaluator for a predetermined amount of time and is then graded on a scale of seriousness by the evaluator. 


\section{REFERENCES}

[1] Ali, B. J., \& Anwar, G. (2021). Factors Influencing the Citizens' Acceptance of Electronic Government. International Journal of Engineering, Business and Management, 5(1), 48-60. https://doi.org/10.22161/ijebm.5.1.5

[2] Saleh, P. F., Ali, B. J., Akoi, S., Najmalddin, B., Ali, R. S., $\&$ Anwar, G. (2021). Factors affecting the Success of Female Entrepreneurs in Kurdistan. International journal of Engineering, Business and Management (IJEBM), 5.

[3] Ali, B. J., \& Anwar, G. (2021). The Effect of Marketing Culture Aspects of Healthcare Care on Marketing Creativity. International Journal of English Literature and Social Sciences, 6(2), 171-182. https://doi.org/10.22161/ijels.62.25

[4] Ali, B. J., \& Anwar, G. (2021). An Empirical Study of Employees' Motivation and its Influence Job Satisfaction. International Journal of Engineering, Business and Management, 5(2), 21-30. https://doi.org/10.22161/ijebm.5.2.3

[5] Ali, B. J., Saleh, P. F., Akoi, S., Abdulrahman, A. A., Muhamed, A. S., Noori, H. N., \& Anwar, G. (2021, May). Impact of Service Quality on the Customer Satisfaction: Case study at Online Meeting Platforms. In Ali, BJ, Saleh, Akoi, S., Abdulrahman, AA, Muhamed, AS, Noori, HN, Anwar, G.(2021). Impact of Service Quality on the Customer Satisfaction: Case study at Online Meeting Platforms. International journal of Engineering, Business and Management (Vol. 5, No. 2, pp. 65-77).

[6] Ali, B. J., \& Anwar, G. (2021). The balanced scorecard's evolution as a strategic mechanism at banking sectors. International Journal of English Literature and Social Sciences, $\quad 6(1), \quad 471-478$. https://doi.org/10.22161/ijels.61.63

[7] Anwar, G., \& Abdullah, N. N. (2021). Inspiring future entrepreneurs: The effect of experiential learning on the entrepreneurial intention at higher education. International Journal of English Literature and Social Sciences, 6.

[8] Ali, B. J., \& Anwar, G. (2021). Measuring competitive intelligence Network and its role on Business Performance. International Journal of English Literature and Social Sciences, 6(2), 329-345. https://dx.doi.org/10.22161/ijels.62.50

[9] Anwar, G., \& Abdullah, N. N. (2021). The impact of Human resource management practice on Organizational performance. International journal of Engineering, Business and Management (IJEBM), 5.

[10] Abdullah, N. N., \& Anwar, G. (2021). An Empirical Analysis of Natural Gas as an Alternative Fuel for Internal Transportation. International Journal of English Literature and Social Sciences, 6(1).

[11] Ali, B. J., \& Anwar, G. (2021). A study of knowledge management alignment with production management: A study of carpet manufacture in Kurdistan region of Iraq. International Journal of English Literature and Social Sciences, 6(2), 346-360. https://dx.doi.org/10.22161/ijels.62.51
[12] Ali, B. J., \& Anwar, G. (2021). The mediation role of change management in employee development. International Journal of English Literature and Social Sciences, 6(2), 361374. https://dx.doi.org/10.22161/ijels.62.52

[13] Anwar, K., \& Louis, R. (2017). Factors Affecting Students' Anxiety in Language Learning: A Study of Private Universities in Erbil, Kurdistan. International Journal of Social Sciences \& Educational Studies, 4(3), 160.

[14] Ali, B. J., \& Anwar, G. (2021). Business strategy: The influence of Strategic Competitiveness on competitive advantage. International Journal of Electrical, Electronics and Computers, 6(2), 1-10. https://dx.doi.org/10.22161/eec.62.1

[15] Anwar, K. (2017). Leading Construction Project Teams: The Effectiveness of Transformational Leadership in Dynamic Work Environments in Kurdistan. International Journal of Advanced Engineering, Management and Science, 3(10), 239925.

[16] Ali, B. J., \& Anwar, G. (2021). Strategic leadership effectiveness and its influence on organizational effectiveness. International Journal of Electrical, Electronics and Computers, 6(2), 11-24. https://dx.doi.org/10.22161/eec.62.2

[17] Anwar, K., \& Qadir, G. H. (2017). A Study of the Relationship between Work Engagement and Job Satisfaction in Private Companies in Kurdistan. International Journal of Advanced Engineering, Management and Science, 3(12), 239944.

[18] Ali, B. J., \& Anwar, G. (2021). Intellectual capital: A modern model to measure the value creation in a business. International journal of Engineering, Business and Management, 5(2), 31-43. https://dx.doi.org/10.22161/ijebm.5.2.4

[19] Ali, B. J., \& Anwar, G. (2021). Marketing Strategy: Pricing strategies and its influence on consumer purchasing decision. International journal of Rural Development, Environment and Health Research, 5(2), 26-39. https://dx.doi.org/10.22161/ijreh.5.2.4

[20] Anwar, K. (2017). Factors Affecting Stock Exchange Investment In Kurdistan. The International Journal of Accounting and Business Society, 25(1), 32-37.

[21] Ali, B. J., \& Anwar, G. (2021). Organization citizenship behaviour as a determining Factor in Business outcome. International journal of Rural Development, Environment and Health Research, 5(2), 17-25. https://dx.doi.org/10.22161/ijreh.5.2.3

[22] Anwar, K., \& Climis, R. (2017). Analyzing the relationship between types of advertisement and customer choice: a study of retailer stores in erbil. The International Journal of Accounting and Business Society, 25(2), 43-52.

[23] Anwar, K., \& Ghafoor, C. (2017). Knowledge management and organizational performance: A study of private universities in Kurdistan. International Journal of Social Sciences \& Educational Studies, 4(2), 53.

[24] Ali, B. J., Saleh, Akoi, S., Abdulrahman, A. A., Muhamed, A. S., Noori, H. N., Anwar, G. (2021). Impact of Service Quality on the Customer Satisfaction: Case study at Online Meeting Platforms. International journal of Engineering, 
Business and Management, 5(2), 65-77. https://dx.doi.org/10.22161/ijebm.5.2.6

[25] Hameed, A. A., \& Anwar, K. (2018). Analyzing the Relationship between Intellectual Capital and Organizational Performance: A Study of Selected Private Banks in Kurdistan. International Journal of Social Sciences \& Educational Studies, 4(4), 39.

[26] Anwar, K. (2017). The Role of Effective Leadership in Crisis Management: Study of Private Companies in Kurdistan. Qalaai Zanist Scientific Journal, 2(4), 326-338.

[27] Anwar, K., \& Balcioglu, H. (2016). The relationship between transformational leadership characteristics and effectiveness: A case study of construction companies in Erbil. International Journal of Science Technology and Management, 5(2), 250-256.

[28] Sabir, B. Y., Othman, B .J., Gardi, B., Ismael, N. B., Hamza, P. A., Sorguli, S., Aziz, H. M., Ahmed, S. A., Ali, B. J., Anwar, G. (2021). Administrative Decentralization: The Transfer of Competency from The Ministry of Education to General Directorates. International Journal of Rural Development, Environment and Health Research, 5(3), 113. https://doi.org/10.22161/ijreh.5.3.1

[29] Abdullah, M. S., Toycan, M., \& Anwar, K. (2017). The cost readiness of implementing e-learning. CUSTOS E AGRONEGOCIO ON LINE, 13(2), 156-175.

[30] Ali, B. J., Anwar, G., Gardi, B., Othman, B. J., Aziz, H. M., Ahmed, S. A., Hamza, P. A., Ismael, N. B., Sorguli, S., Sabir, B. Y. (2021). Business Communication Strategies: Analysis of Internal Communication Processes. Journal of Humanities and Education Development, 3(3), 16-38. https://doi.org/10.22161/jhed.3.3.4

[31] Anwar, K. (2016). Comparison between cost leadership and differentiation strategy in agricultural businesses. Custos E Agronegocio on Line, 12(2), 212-231.

[32] Ali, B. J., Gardi, B., Othman, B. J., Ismael, N. B., Sorguli, S., Sabir, B. Y., Ahmed, S. A., Hamza, P. A., Aziz, H. M., Anwar, G. (2021). Educational system: The policy of Educational system in Kurdistan Region in public Kindergarten. International Journal of English Literature and Social Sciences, 6(3), 062-071. https://doi.org/10.22161/ijels.63.10

[33] Anwar, K. (2017). Analyzing the conceptual model of service quality and its relationship with guests'satisfaction: a study of hotels in erbil. The International Journal of Accounting and Business Society, 25(2), 1-16.

[34] Aziz, H. M., Othman, B. J., Gardi, B., Ahmed, S. A., Sabir, B. Y., Ismael, N. B., Hamza, P. A., Sorguli, S., Ali, B. J., Anwar, G. (2021). Employee Commitment: The Relationship between Employee Commitment And Job Satisfaction. Journal of Humanities and Education Development, 3(3), 54-66. https://doi.org/10.22161/jhed.3.3.6

[35] Anwar, G., \& Shukur, I. (2015). The Impact of Service Quality Dimensions on Students' Satisfaction. International Journal of Social Sciences \& Educational Studies, 76.

[36] Ali, B. J., Gardi, B., Othman, B. J., Ahmed, S. A., Ismael, N. B., Hamza, P. A., Aziz, H. M., Sabir, B. Y., Anwar, G. (2021). Hotel Service Quality: The Impact of Service
Quality on Customer Satisfaction in Hospitality. International Journal of Engineering, Business and Management, 5(3), 14-28. https://doi.org/10.22161/ijebm.5.3.2

[37] Anwar, G., \& Surarchith, N. K. (2015). Factors Affecting Shoppers' Behavior in Erbil, Kurdistan-Iraq. International Journal of Social Sciences \& Educational Studies, 1(4), 10.

[38] Sorguli, S., Gardi, B., Othman, B.J., Aziz, H. M., Ahmed, S. A., Sabir, B. Y., Ismael, N. B., Hamza, P. A., Ali, B. J., Anwar, G. (2021) Innovation: Knowledge Management in the Innovating Industries, 6(3), 10-23. https://dx.doi.org/10.22161/eec.63.2

[39] Anwar, G., \& Abd Zebari, B. (2015). The Relationship between Employee Engagement and Corporate Social Responsibility: A Case Study of Car Dealership in Erbil, Kurdistan. International Journal of Social Sciences \& Educational Studies, 2(2), 45.

[40] Hamza, P. A., Othman, B. J., Gardi, B., Sorguli, S., Aziz, H. M., Ahmed, S. A., Sabir, B. Y., Ismael, N. B., Ali, B. J., Anwar, G. (2021). Recruitment and Selection: The Relationship between Recruitment and Selection with Organizational Performance. International Journal of Engineering, Business and Management, 5(3), 1-13. https://doi.org/10.22161/ijebm.5.3.1

[41] Anwar, G., \& Shukur, I. (2015). the impact of recruitment and selection on job satisfaction: Evidence from private school in Erbil. International Journal of Social Sciences \& Educational Studies, 1(3), 4-13.

[42] Ali, B. J., Gardi, B., Othman, B. J., Sabir, B. Y., Sorguli, S., Ismael, N. B., Hamza, P.A., Aziz, H. M., Ahmed, A. A., Anwar, G. (2021). The Role of Shopping Malls on Kurdistan Regional Government's Economy. Journal of Humanities and Education Development, 3(3), 39-53. https://doi.org/10.22161/jhed.3.3.5

[43] Anwar, G., \& Shukur, I. (2015). Job satisfaction and employee turnover intention: A case study of private hospital in Erbil. International Journal of Social Sciences \& Educational Studies, 2(1), 73.

[44] Ahmed, S. A., Othman, B. J., Gardi, B., Sabir, B. Y., Ismael, N. B., Hamza, P. A., Sorguli, S., Aziz, H. M., Ali, B. J., Anwar, G. (2021). Students' Attitudes towards Learning English in the Kurdistan region of Iraq. International Journal of English Literature and Social Sciences, 6(3), 072-087. https://doi.org/10.22161/ijels.63.11

[45] Anwar, G., \& Shukur, I. (2015). The Impact of Training and Development on Job Satisfaction: A Case Study of Private Banks in Erbil. International Journal of Social Sciences \& Educational Studies, 2(1), 65. 